\title{
Preventive measures against the COVID-19 pandemic in Mexico: A cross-sectional study
}

Juan Carlos Ibarrola-Peña

Centro Médico Nacional de Occidente

Francisco José Barbosa-Camacho

Centro Médico Nacional de Occidente

Yolanda Lorelei Almanza-Mena

Centro Médico Nacional de Occidente

Jonathan Matias Chejfec-Ciociano

Centro Médico Nacional de Occidente

Emilio Alberto Reyes-Elizalde

Centro Médico Nacional de Occidente

Olaya Moramay Romero-Limón

Universidad de Guadalajara

Rafael Zaragoza-Organista

Centro Médico Nacional de Occidente

Enrique Cervantes-Pérez

Instituto Nacional de Ciencias Médicas y Nutrición "Salvador Zubirán"

José Hector Sapién-Fernández

Centro Médico Nacional de Occidente

José Aldo Guzmán-Barba

Centro Médico Nacional de Occidente

Paola Flores-Becerril

Centro Médico Nacional de Occidente

Martín López-Zendejas

Hospital San Javier Guadalajara

Clotilde Fuentes-Orozco

Centro Médico Nacional de Occidente

Gabino Cervantes-Guevara

Universidad de Guadalajara

Roberto Carlos Miranda-Ackerman

Hospital San Javier Guadalajara

Alejandro González-0jeda ( $\nabla$ avygail5@gmail.com )

Centro Médico Nacional de Occidente 


\section{Research Article}

Keywords: Health behavior, Pandemic, Risk-taking, Mexico, COVID-19

Posted Date: April 1st, 2021

DOl: https://doi.org/10.21203/rs.3.rs-373068/v1

License: (c) (i) This work is licensed under a Creative Commons Attribution 4.0 International License. Read Full License 


\section{Abstract}

Background: In December 2019, the World Health Organization announced a new viral pneumonia due to SARS-CoV-2, which originated in Wuhan, China. In Mexico, the official announcement regarding the first coronavirus disease 2019 (COVID-19) case was made on February 29, 2020. Understanding how Mexicans behave during the pandemic could present a complete picture of the pandemic in Mexico while providing better handling of the pandemic.

Methods: This was a cross-sectional survey in which we inquired about the Mexican population's behavior and preventive measures. In total, 4004 subjects from the general population responded to the survey. The survey comprised a questionnaire that included demographic data, housing conditions, daily coexistence with people, use of preventive measures, confidence in the Mexican health-care sector, acceptance of medical procedures, and knowledge of COVID-19.

Results: Participants' mean age was $30 \pm 13.7$ years, and $43.8 \%$ of participants reported at least one comorbidity. Almost $99 \%$ of the participants mentioned knowing the symptoms of COVID-19. Moreover, $68.1 \%$ of them lived with three to five cohabitants, and $87.4 \%$ of them stated that at least one household member had to break social isolation every week. Although $77.5 \%$ of participants considered that they followed proper social distancing measures, $60 \%$ of them mentioned that they knew at least six individuals who did not follow social distancing measures. Furthermore, $96.2 \%$ of participants reported using preventive measures at least $50 \%$ of the time. Face masks were used by $99.5 \%$ of them, but only $51.3 \%$ used a certified mask.

Conclusions: The COVID-19 pandemic outcomes in Mexico are the result of multiple negative factors, such as high rates of comorbidities (e.g., diabetes and hypertension); a high number of people living together at home, with many people breaking social isolation; and most of the population using noncertified preventive measures, which may not have the necessary effectiveness.

\section{Background}

At the end of 2019, a series of atypical pneumonia cases were reported in Asia at that time of unknown origin. Days later, the etiologic agent was identified as a new coronavirus [1]. In December 2019, the World Health Organization (WHO) announced a new viral pneumonia due to SARS-CoV-2, which originated in Wuhan, China [2]. The virus spread rapidly worldwide, wreaking havoc first in Asia and then spreading to the rest of the world. The coronavirus disease 2019 (COVID-19) pandemic struck Latin America in late February and is now beginning to spread across the region's rural indigenous communities, home to 42 million people [3].

In Mexico, the official announcement regarding the first COVID-19-infected patient was made on February 29, 2020 [4]. On March 18, 2020, the Secretariat of Health of Mexico reported that 250,656 COVID-19 cases were expected. This amounts to roughly $0.19 \%$ of Mexico's total population, estimated to be approximately 130.8 million in 2018 [5]. By March 2021, the Mexican government's official website 
reported a total of 2,358,167 cases in the country, of which 46,870 were active at that moment, and 214,959 were cases of death [6]. Mexico had a fatality rate of $8.5 \%$, which was the highest among the Latin American countries, followed by Peru, with a fatality rate of 3.5\% [7].

Almost 12 months after the initiation of the COVID-19 pandemic, the spread of the coronavirus in Mexico exceeded government predictions by $>1$ million cases, and the incidence of COVID-19 continues to increase rapidly.

The Mexican government's epidemiological strategies were late, ineffective, and constantly contradictory. Its messaging was confusing to its population, which was even invited on multiple occasions by its president to break social isolation [8], despite the WHO's recommendations [9]. Nevertheless, although its government indeed decides the way a country faces a crisis, it would be imprecise and naive to think that government decisions are the unique factor that influences the outcome of the pandemic when it is known that the main element to achieving a successful preventive health-care program is the behavior of its population. Mexicans cannot stay in strict isolation for several reasons, such as poverty, lack of government support, and the need to keep their jobs and continue their businesses. It is the reality that a vast majority of the Mexican population cannot socially distance, even if they want to. Furthermore, Mexicans, similar to most Latin American populations, are especially susceptible to the rapid spread of the virus with a high incidence of cases and deaths due to the high prevalence of obesity, chronic degenerative diseases, and deficiencies in public health-care systems, on which the majority of the population is dependent.

We conducted this study to understand the Mexican population's actual behavior, their preventive measures, and protocols, not only those implemented by the government but also those they followed during the COVID-19 pandemic. Understanding population behavior during the pandemic will enable future projections of the possible outcomes of this pandemic and future pandemics in a broader context, beyond just epidemiological tracking.

\section{Methods}

\section{Aims}

This study aimed to identify the risk factors favoring the COVID-19 contagion by studying the Mexican population's quarantine behavior and preventive measures. As a secondary aim, we sought to identify areas that needed reinforcement to develop strategies for a successful plan for upcoming pandemics.

\section{Study design}

This study used a cross-sectional survey to inquire about the general Mexican population's behavior during the quarantine, such as using preventive measures (face masks, alcohol-based hand sanitizers, and face shields). 


\section{Study sample}

A total of 4029 subjects were surveyed, but only 4004 were included in this study. The study population was selected for convenience using digital media, where the general population was asked to share the survey with their friends and family. The inclusion criteria were Mexican citizens or residents of Mexico and $>15$ years of age. The exclusion criteria were $<15$ years of age, those with incomplete surveys, tourists currently staying in the country, or Mexican but residing in another country. The complete demographic characteristics of the participants are presented in Table 1.

Table 1 Participant demographics. 


\begin{tabular}{|c|c|}
\hline & Sample $(n=4004)$ \\
\hline & $\mathrm{n}(\%)$ \\
\hline \multicolumn{2}{|l|}{ Sex } \\
\hline Male & $1335(33.3 \%)$ \\
\hline Female & $2669(66.7 \%)$ \\
\hline \multicolumn{2}{|l|}{ Age, years } \\
\hline Mean (standard deviation) & $30.01(13.72)$ \\
\hline $15-25$ & $1238(30.9)$ \\
\hline $26-50$ & $2037(50.9)$ \\
\hline 50 or more & $729(18.2)$ \\
\hline \multicolumn{2}{|l|}{ School education } \\
\hline Elementary & $987(24.7)$ \\
\hline Higher & $3017(75.3)$ \\
\hline \multicolumn{2}{|l|}{ Occupation } \\
\hline Formal job & $2351(58)$ \\
\hline Informal job & $302(7.5)$ \\
\hline Student & $822(20.5)$ \\
\hline Retired & $135(3.4)$ \\
\hline Neither working nor studying & $150(3.7)$ \\
\hline Other & $244(6.1)$ \\
\hline \multicolumn{2}{|l|}{ Residency state } \\
\hline Jalisco & $2240(55.94)$ \\
\hline Other & $1764(44.05)$ \\
\hline \multicolumn{2}{|l|}{ Comorbidities } \\
\hline None & $2247(56.11)$ \\
\hline Overweight & $1272(31.76)$ \\
\hline Diabetes & $165(4.12)$ \\
\hline Hypertension & $330(8.24)$ \\
\hline Other & $482(12.03)$ \\
\hline
\end{tabular}




\begin{tabular}{|ll|}
\hline Number of comorbidities & \\
\hline 1 & $2247(56.11)$ \\
\hline 2 or more & $1153(28.79)$ \\
\hline Substance use & $650(16.23)$ \\
\hline None & $1119(27.94)$ \\
\hline Tobacco & $538(13.43)$ \\
\hline Alcohol & $1129(28.19)$ \\
\hline Cannabis or other drugs & $123(3.07)$ \\
\hline Coffee & $2199(54.92)$ \\
\hline Number of substance types & \\
\hline 1 & $1961(48.97)$ \\
\hline 2 & $715(17.85)$ \\
\hline 3 & $209(5.21)$ \\
\hline
\end{tabular}

\section{Survey instrument}

The survey instrument comprised a questionnaire that included demographic data, such as sex, age, school education level, and occupation. The survey also included questions about illnesses; consumption of substances such as alcohol, tobacco, coffee, and drugs; housing conditions; daily coexistence with people; use of preventive measures against COVID-19; confidence in the Mexican health sector; and general knowledge of the disease. The survey was completed completely anonymously and voluntarily using Google Forms. The survey can be found in Additional file 1.

\section{Data analysis}

The data were analyzed using IBM SPSS Statistics (version 23.0 for Windows). Proportions, means, and standard deviations were included for the descriptive analyses. The inferential analysis of categorical variables was performed using the chi-square test, Fisher's exact probability test, or variance analysis as appropriate. Student's t-test was used to analyze continuous variables. A probability level of $p<0.05$ was considered significant.

\section{Results}


A total of 4029 subjects responded to the survey. Twenty-five surveys were excluded from the study due to being incomplete, leading to 4004 participants: 2669 female (66.7\%) and 1335 male (33.3\%) participants. The mean participant age was $30.01 \pm 13.72$ years. The participants were divided into two levels of education groups: an elementary education group (EEG), which included 987 participants $(24.6 \%)$ with primary and high school level education, and a higher education group (HEG), which included 3017 participants (75.3\%) with college and university level education. The complete demographic characteristics of the participants are presented in Table 1.

\section{Knowledge of COVID-19}

For the question "Do you stay informed about the pandemic in your country and state?" only 2392 participants (59.7\%) answered "yes," with a significant difference between the number of such respondents in the EEG and HEG $(p<0.001)$ (510 participants [51.6\%] and 1882 participants [62.3\%], respectively). A total of 3954 participants (almost 99\%) mentioned knowing the symptoms of COVID-19, and almost $90 \%$ of the participants mentioned knowing where they could go in case of having current symptoms of COVID-19.

\section{Daily coexistence with people}

In response to the question "How many people live in your household?", 2728 participants (68.1\%) mentioned 3-5 cohabitants, and nearly 3091 participants (77.1\%) lived with $>3$ cohabitants. The tendency to live with a greater number of people ( $>3$ cohabitants) was more noticeable in the EEG than in the HEG (828 participants [83.8\%] versus 2263 participants [75\%], respectively). Moreover, a similar trend was observed for ">6 cohabitants" (124 participants [12.5\%] in the EEG versus 239 participants [7.9\%] in the HEG). When asked "How often do they find themselves in need to break social isolation and leave home?", we divided the sample into two groups: 3502 participants (87.4\%) stated that at least one household member must break the isolation per week (2774 participants [69.3\%] with "1-2 cohabitants" and 728 participants [ $18.18 \%$ ] with " $3-5$ cohabitants"). The frequency of the need to break social isolation by at least one household member was not significantly higher either EEG or HEG (530 participants [53.6\%] versus 1644 participants [54.4\%], respectively $(p=0.345)$.

\section{Breaking social isolation}

For the question "Do you consider that you are following the proper rules for social distancing?" approximately 3106 participants $77.57 \%$ answered "yes," with a slight difference between the number of participants who believed that they were not maintaining an adequate social distance in the EEG and HEG (273 participants [27.6\%] and 625 participants [20.7\%], respectively) This difference was statistically different $(p<0.001)$. Regarding social distancing, 2174 participants $(54.2 \%)$ mentioned that they broke social isolation at least once per week in the last month, 1306 participants $(32.6 \%)$ stated that they went 
outside at least once in the last month, and only 524 participants (13.1\%) did not go outside at all. Regarding how people who could not stay at home adapted their lives to follow social distancing measures as much as possible, 1678 participants (41.9\%) stated, "I go to work but remain outside home as less as possible," 1600 participants (39.9\%) stated, "I leave home exclusively for essential activities." The remaining participants stated, "I have decreased my activities involving exposure to a large number of people, but I keep going outside."

After probing their behavior regarding social distancing, we asked the participants, "How many people in your closest circle do you consider not to be following adequate social distancing measures and behaving irresponsibly?" All participants stated that they knew someone who was not following social distancing measures imposed by the government. A total of 2257 participants (nearly $60 \%$ ) stated that they knew $>6$ individuals who were not following social distancing measures. It appeared that it was easier for the participants to indicate lousy behavior in others rather than admit to their bad behavior. Only 172 participants (4.3\%) stated that they had not interacted with people other than their cohabitants. Moreover, 3831 participants (95.6\%) mentioned interacting with $>1$ person who was not their cohabitant. Notably, $37 \%$ of participants interacted with $>6$ individuals, and $20 \%$ interacted with $>11$ individuals.

After probing the participants regarding their degrees of social distancing and exposure, we asked them, "Based on your daily activities, what is the risk that you think you have of contracting COVID-19?" 2690 participants (67.1\%) answered "low-to-medium risk," and only 1312 participants (32.7\%) thought that they had a "high risk" of COVID-19 infection.

We also asked them why they could not adequately maintain social distancing measures and why they believed that the Mexican population could not maintain social distancing measures. These findings are presented in Table 2.

Table 2 Question: Why do you break social isolation rules? Description: Participants were allowed to select at least one option and at most two options. Percentages were calculated based on the total sample $(n=4004)$, not the total number of answers. 


\begin{tabular}{|c|c|c|c|c|}
\hline $\begin{array}{l}\text { Complete } \\
\text { disinterest }\end{array}$ & $\begin{array}{l}\text { Need } \\
\text { to } \\
\text { work }\end{array}$ & $\begin{array}{l}\text { Despair and } \\
\text { need for } \\
\text { recreational } \\
\text { activities }\end{array}$ & $\begin{array}{l}\text { Family } \\
\text { visits }\end{array}$ & Errands \\
\hline
\end{tabular}

\section{Age, years}

\begin{tabular}{lllllll}
\hline $15-25$ & 18 & 472 & 300 & 276 & 663 & 90 \\
\hline $26-50$ & 17 & 1277 & 132 & 348 & 936 & 67 \\
\hline 50 or more & 3 & 301 & 21 & 78 & 456 & 50 \\
\hline Total & 38 & 2050 & 453 & 702 & 2055 & 207 \\
$\begin{array}{l}\text { Percentage of answers from } \\
\text { the total sample (n= 4004) }\end{array}$ & 0.94 & 51.19 & 11.31 & 17.53 & 51.32 & 5.16 \\
\hline $\begin{array}{l}\text { Percentage of answers from } \\
\text { participants who broke } \\
\text { social isolation }(\mathrm{n}=3797)\end{array}$ & 1 & 53.98 & 11.93 & 18.48 & 54.12 & - \\
\hline $\begin{array}{l}\text { Sex } \\
\text { Sex }\end{array}$ & & & & & &
\end{tabular}

\section{Sex}

Male

Percentage of answers from

male participants $(n=1335)$

17

$829 \quad 228$

1.2

62.09

16.7

231

596

34

Female

21

Percentage of answers from
female participants $(\mathrm{n}=$
$2669)$

3.13

$1241 \quad 225$

17.3

44.64

2.54
Total
Percentage of answers from $\quad 0.94$
the total sample $(n=4004)$
Percentage of answers from 1 participants who broke social isolation $(n=3797)$

\section{School education}

\begin{tabular}{|c|c|c|c|c|c|c|}
\hline Elementary & 16 & 520 & 129 & 169 & 477 & 55 \\
\hline $\begin{array}{l}\text { Percentage of answers from } \\
\text { participants with elementary } \\
\text { education }(n=987)\end{array}$ & 1.62 & 52.68 & 13.06 & 17.122 & 48.32 & 5.57 \\
\hline Higher & 22 & 1530 & 324 & 533 & 1578 & 152 \\
\hline $\begin{array}{l}\text { Percentage of answers from } \\
\text { participants with higher }\end{array}$ & - & $50 . .17$ & 10.73 & 17.66 & 52.3 & 5 \\
\hline
\end{tabular}


education $(n=3017)$

Total 38

Percentage of answers from

0.94

2050

453

702

2055

207

the total sample $(n=4004)$

Percentage of answers from participants who broke

$51.19 \quad 11.31$

17.53

51.32

5.16

social isolation $(n=3797)$

\section{Personal preventive measures against COVID-19}

We asked the participants how often they used preventive measures against COVID-19. To our surprise, 3852 participants (approximately $96.20 \%$ ) used preventive measures at least $50 \%$ of the time, and 2813 participants (almost 70.25\%) stated that they used it all the time. However, like all questions that include a similar one but that applies to the rest of the population, it appears easier to see in the others because when we asked the participants about the percentage of people they see on the street using preventive measures against COVID-19. Approximately $70 \%$ of participants answered that more than half of the people they see on the street use preventive measures against COVID-19, and this included 1087 participants who stated that $<25 \%$ of the people on the street use preventive measures.

We also asked them the reasons as to why they did not use preventive measures against COVID-19 all the time and their opinion on why they believed that Mexicans were not using preventive measures all the time. These findings are shown in Table 3. Table 4 presents the type of preventive measures against COVID-19 used by the study participants.

Table 3 Question: Why do you not use preventive measures against coronavirus all the time? Description: Participants were allowed to select at least one option and at most two options. Percentages were calculated based on the total sample $(n=4004)$, not the total number of answers. 


\begin{tabular}{|c|c|c|c|c|c|c|c|}
\hline & Disinterest & $\begin{array}{l}\text { It is } \\
\text { tiring } \\
\text { to } \\
\text { use } \\
\text { them }\end{array}$ & $\begin{array}{l}\text { It is } \\
\text { difficult } \\
\text { for me } \\
\text { to buy } \\
\text { them }\end{array}$ & $\begin{array}{l}\text { It is } \\
\text { expensive } \\
\text { to use } \\
\text { them all } \\
\text { the time }\end{array}$ & $\begin{array}{l}\text { I do not } \\
\text { think } \\
\text { that } \\
\text { you } \\
\text { need to } \\
\text { use } \\
\text { them } \\
\text { all the } \\
\text { time }\end{array}$ & $\begin{array}{l}\text { I think it is } \\
\text { unlikely } \\
\text { that I will } \\
\text { be infected } \\
\text { by } \\
\text { coronavirus }\end{array}$ & $\begin{array}{l}\text { It } \\
\text { does } \\
\text { not } \\
\text { apply: } \\
\text { l use } \\
\text { them } \\
\text { all the } \\
\text { time }\end{array}$ \\
\hline \multicolumn{8}{|l|}{ Sex } \\
\hline Male & 32 & 138 & 104 & 69 & 167 & 49 & 871 \\
\hline $\begin{array}{l}\text { Percentage of } \\
\text { answers from } \\
\text { male participants } \\
(n=1335)\end{array}$ & 2.39 & 10.33 & 7.79 & 5.1 & 12.5 & 3.67 & 65.24 \\
\hline Female & 54 & 280 & 117 & 112 & 216 & 63 & 1923 \\
\hline $\begin{array}{l}\text { Percentage of } \\
\text { answers from } \\
\text { female } \\
\text { participants ( } \mathrm{n}= \\
\text { 2669) }\end{array}$ & 2.02 & 10.49 & 4.38 & 4.19 & 5.39 & 2.3 & 72.04 \\
\hline Total & 86 & 418 & 221 & 181 & 383 & 112 & 2794 \\
\hline $\begin{array}{l}\text { Percentage of } \\
\text { answers from the } \\
\text { total sample }(n= \\
4004)\end{array}$ & 2.14 & 10.49 & 5.51 & 4.52 & 9.56 & 2.79 & 69.78 \\
\hline \multicolumn{8}{|l|}{ School education } \\
\hline Elementary & 61 & 138 & 75 & 74 & 126 & 34 & 575 \\
\hline $\begin{array}{l}\text { Percentage of } \\
\text { answers from } \\
\text { participants with } \\
\text { elementary } \\
\text { education ( } \mathrm{n}= \\
\text { 987) }\end{array}$ & 6.1 & 13.98 & 7.59 & 7.49 & 12.76 & 3.44 & 58.25 \\
\hline Higher & 25 & 280 & 146 & 107 & 257 & 78 & 2219 \\
\hline $\begin{array}{l}\text { Percentage of } \\
\text { answers from } \\
\text { participants with } \\
\text { higher education } \\
(\mathrm{n}=3017)\end{array}$ & 0.82 & 9.28 & 4.83 & 3.54 & 8.51 & 2.58 & 73.54 \\
\hline Total & 86 & 418 & 221 & 181 & 383 & 112 & 2794 \\
\hline $\begin{array}{l}\text { Percentage of } \\
\text { answers from the } \\
\text { total sample }(n= \\
4004)\end{array}$ & 2.14 & 10.49 & 5.51 & 4.52 & 9.56 & 2.79 & 69.78 \\
\hline
\end{tabular}


Occupation

\begin{tabular}{|c|c|c|c|c|c|c|c|}
\hline Formal job & 38 & 231 & 146 & 109 & 246 & 48 & 1652 \\
\hline $\begin{array}{l}\text { Percentage of } \\
\text { answers from } \\
\text { participants with } \\
\text { a formal job }(n= \\
2351)\end{array}$ & 1.61 & 9.82 & 6.21 & 4.63 & 10.46 & 2.04 & 70.26 \\
\hline Informal job & 16 & 36 & 29 & 31 & 40 & 13 & 175 \\
\hline $\begin{array}{l}\text { Percentage of } \\
\text { answers from } \\
\text { participants with } \\
\text { an informal job (n } \\
=302)\end{array}$ & 5.29 & 11.92 & 9.6 & 10.26 & 13.24 & 4.3 & 57.94 \\
\hline Student & 21 & 107 & 29 & 28 & 74 & 31 & 581 \\
\hline $\begin{array}{l}\text { Percentage of } \\
\text { answers from } \\
\text { students }(n=822)\end{array}$ & 2.55 & 13.01 & 3.52 & 3.4 & 9 & 3.77 & 70.68 \\
\hline Retired & 3 & 11 & 1 & 2 & 13 & 6 & 101 \\
\hline $\begin{array}{l}\text { Neither working } \\
\text { nor studying }\end{array}$ & 6 & 13 & 8 & 6 & 0 & 6 & 107 \\
\hline Other & 2 & 20 & 8 & 5 & 7 & 8 & 178 \\
\hline Total & 86 & 418 & 221 & 181 & 383 & 112 & 2794 \\
\hline $\begin{array}{l}\text { Percentage of } \\
\text { answers from the } \\
\text { total sample }(n= \\
4004)\end{array}$ & 2.14 & 10.49 & 5.51 & 4.52 & 9.56 & 2.79 & 69.78 \\
\hline \multicolumn{8}{|l|}{ Total } \\
\hline Total & 1874 & 588 & 127 & 463 & 1952 & 993 & - \\
\hline $\begin{array}{l}\text { Percentage of } \\
\text { answers from the } \\
\text { total sample }(n= \\
4004)\end{array}$ & 46.8 & 14.68 & 3.17 & 11.56 & 48.75 & 24.8 & - \\
\hline
\end{tabular}

Table 4 Preventive measures against COVID-19. Description: Certified face masks defined as those distributed by pharmaceutical companies, pharmacies, or health-care personnel. Noncertified face masks defined as those custom made, homemade, or noncertified for health-care personnel use. 


\begin{tabular}{|lllllll|}
\hline Face masks & Basic & 987 & Superior & 3017 & Total & 4004 \\
\hline Certified face mask & 495 & 50.15 & 1563 & 51.8 & 2058 & 51.39 \\
\hline Noncertified face mask & 482 & 48.83 & 1444 & 47.86 & 1926 & 48.1 \\
\hline I do not use any face mask & 10 & 1.01 & 10 & 0.33 & 20 & 499 \\
\hline Total & 987 & - & 3017 & - & 4004 & - \\
\hline Mask/Safety eyewear & Basic & 987 & Superior & 3017 & Total & 4004 \\
\hline Certified face mask or safety eyewear & 270 & 27.35 & 746 & 24.72 & 1016 & 25.37 \\
\hline Noncertified face mask & 225 & 22.79 & 853 & 28.27 & 1078 & 26.92 \\
\hline I do not use any face mask & 492 & 49.84 & 1418 & 47 & 1910 & 47.7 \\
\hline Total & 987 & - & 3017 & - & 4004 & - \\
\hline Alcohol-based sanitizer & Basic & 987 & Superior & 3017 & Total & 4004 \\
\hline Certified alcohol-based sanitizer & 820 & 83.08 & 2582 & 85.58 & 3402 & 84.96 \\
\hline Noncertified alcohol-based sanitizer & 132 & 13.37 & 399 & 13.22 & 531 & 13.26 \\
\hline I do not use any sanitizer & 35 & 3.54 & 36 & 1.19 & 71 & 1.773 \\
\hline Total & 987 & - & 3017 & - & 4004 & - \\
\hline
\end{tabular}

\section{COVID-19 screening test}

Considering the Mexican population's exposure to COVID-19, it is essential to know how many participants in this study had been tested for COVID-19 to determine if they were following a good preventive health-care program. A total of 3502 participants (approximately $87.46 \%$ ) had never undergone COVID-19 testing, and of the remaining 502 participants (12.53\%), 389 had a negative test result, and only 133 had a positive test result. When we asked the participants, "Do you know anybody who has presented symptoms of or has been diagnosed with COVID-19?", 2880 participants $(71.92 \%)$ reported knowing at least one person who had been diagnosed with COVID-19.

\section{The Mexican health-care system}

We asked the participants if they believed that hospitals in Mexico were prepared to face the pandemic crisis, pointing out the differences between the public and private health-care systems. A total of 2501 (62.46\%) and 2676 participants $(66.83 \%)$ believed that public and private hospitals were prepared for the pandemic, respectively. By level of education, 1919 participants (63.60\%) from the HEG and 582 
participants (58.9\%) from the EEG responded that they believed that the public health-care system was prepared for the pandemic $(\mathrm{p}<0.01)$. Furthermore, 2043 participants $(67.71 \%)$ of the HEG and 633 participants $(64.13 \%)$ of the EEG responded that they believed that private hospitals were prepared for the pandemic $(p<0.05)$. Then, we asked the participants about the factors they thought influenced the Mexican health-care system's inability to be prepared for a pandemic. The participants could select more than one answer for this question. The most selected answer ( $65.58 \%$ of participants) was "The facilities and equipment required to deal with the pandemic situation are not available." followed by "The healthcare personnel does not have enough supplies" (59.94\% of participants), and "There are not enough health-care personnel to serve the entire population" (43.32\% of participants). Only $5.49 \%$ of participants thought that the doctors and health-care personnel were not sufficiently prepared to face the pandemic.

\section{Discussion}

\section{The general state of Mexico and its population}

In attempting to understand the scope of COVID-19 infections in Mexico, we found that the especially susceptible population (aged $>60$ years) in Mexico represented approximately $12.5 \%$ of the population (approximately 15.4 million people), of which at least $69.4 \%$ had some type of disability, according to data reported by the National Institute of Statistics and Geography (INEGI) [10]. In our study, 729 participants (approximately 18.2\%) were in the susceptible age group. By August 2020, of the almost 57,000 registered deaths due to COVID-19 in Mexico, $58 \%$ of cases were adults aged $>60$ years [11]. According to the Korea Centers for Disease Control and Prevention, the overall case fatality rate (CFR) in Korea was $2.37 \%$ in 11,344 patients with confirmed cases of COVID-19 infection as of May 28, 2020, but it was much higher in the elderly $(10.9 \%$ in patients aged $70-79$ years and $26.6 \%$ in patients aged $>80$ years) [12]. For 44,672 diagnosed cases of COVID-19 as of February 11,2020 , the overall CFR was $2.3 \%$ in China. However, the CFR was $8.0 \%$ in patients aged $70-79$ and $14.8 \%$ in patients aged $>80$ years [13]. Thus, older adults are advised to stay home while maintaining social distancing measures to prevent COVID-19 infection.

Another factor that makes the Mexican population highly vulnerable to COVID-19 infection is the high incidence of chronic diseases and metabolic disorders, which is caused by a poor health-care culture comprising an inadequate routine of aerobic exercises, poor diet with limited nutritional content, and high caloric intake and null culture of preventive medicine. Up to $47.40 \%$ of patients with COVID-19 were reported to have at least one comorbidity, with hypertension being the most frequent comorbidity (20.12\%). The comorbidities that most increased the risk of intensive care unit stay and intubation were diabetes, immunosuppression, and obesity [14]. In this study, 1803 participants (almost 43.89\%) had at least one comorbidity. The Centers for Disease Control and Prevention reported that Mexicans are more likely to have type 2 diabetes (17\%) than non-Hispanic whites (8\%) [15]. In this study, 165 participants (4.12\%) had diabetes. Moreover, INEGI reported that 8,600,000 people in Mexico had diabetes mellitus in 2018 [16]. Diabetes is a factor used to assess the severity of COVID-19 cases. In a Mexican study, of approximately 373,963 adults with COVID-19, $16.1 \%$ had diabetes. The predicted probability of 
hospitalization was $38.4 \%$ (37.6-39.2) for patients with diabetes only and $42.9 \%$ (42.2-43.7) for those with diabetes and one or more comorbidities [17]. Regarding arterial hypertension in Mexico, according to the National Health and Nutrition Survey of Medio Camino 2016, carried out by the National Institute of Public Health (INSP) and the Ministry of Health, one in four adults in Mexico had arterial hypertension. Approximately $40 \%$ of these patients were unaware they had this condition, which affected their health, and of the approximately $60 \%$ of patients who knew about the diagnosis, the condition was controlled in only half of the patients [18]. In this study, 330 participants were diagnosed with arterial hypertension.

Moreover, the SARS-CoV-2 virus uses receptors on the cells in the lungs to cause infection, regulating blood pressure as direct routes to infect cells, using angiotensin-converting enzyme 2 (ACE2). Patients with hypertension can have changes in ACE2, either in its structure or expression level, which makes it easier for the virus to cause a more severe infection. ACE2 levels may be increased in patients with cardiovascular disease. The available data associate baseline comorbidities with a severe course of COVID-19 [19], and interrupting anti-hypertensive treatment can precipitate cardiovascular decompensation [20].

Regarding obesity and overweight, INEGI in 2018 reported that the age group that reports the highest prevalence of obesity is the age group of $30-59$ years, and $35 \%$ of men and $46 \%$ of women have obesity. Regarding the prevalence of obesity, a high prevalence is observed for the population aged 12-19 years $(17 \%)$ and $>20$ years (42\%) in the northern region of Mexico [21]. In this study, 1272 participants (31.76\%) had a diagnosis of obesity. A previous study showed that obesity is a risk factor for hospitalization, admission to the intensive care unit, and the development of severe consequences that lead to death in cases of COVID-19 [22]. A French study showed that severely obese patients (body mass index >35) require invasive mechanical ventilation more frequently than lean patients, regardless of age, sex, diabetes, and high blood pressure [23]. Considering the Mexican population's health condition, it is easy to understand why the COVID-19 fatality rate reached such high levels and why the prevention policies were directed toward isolating the population at risk, representing a large percentage of the Mexican population.

Many other factors contribute to Mexico's pandemic situation, including some difficult to control, such as weather and air pollution. A Mexican study reported that in Mexico, climatic conditions played a crucial role in local infection during phase 1 of the COVID-19 pandemic making temperate regions, such as Michoacán, Jalisco, and Puebla, more vulnerable than dry regions, such as Chihuahua, Durango, and Zacatecas, or tropical regions, such as Colima, Campeche, and Morelos [4]. Another Mexican study attempted to determine the relationship between air pollution in Mexico City and severe COVID-19 cases. It concluded that for Mexico City, there was evidence of a positive relationship between pollution and mortality, which increased significantly with age and appeared to be driven mainly by long-term exposure rather than short-term exposure to pollution [24]. Nevertheless, probably the most critical factors to influence the COVID-19 pandemic's development in Mexico are the status of the health-care system and government strategies. Accordingly, a study published in December 2020 strongly criticized Mexico's position on the pandemic. It stated that Mexico's vast inequality, underfunded health-care system, 
sizeable informal economy, and belts of cramped, multigenerational housing made it particularly vulnerable to the spread of the virus. However, a lack of strategy, combined with the president's mixed messages, has exacerbated the situation in a poorly equipped country to handle a pandemic [25].

Regarding this lack of a sound health-care system, we asked the participants about their confidence in the Mexican health-care system; almost $40 \%$ of the participants disapproved of the system. The reasons why they thought that hospitals were not prepared for the pandemic were: "The facilities and equipment required to deal with the pandemic situation are not available" (according to $65 \%$ of participants), "Healthcare personnel do not have enough supplies" (59\% of participants), and "There are not enough health-care personnel to serve the entire population" (43\% of participants). This finding indicated that almost half of our study participants considered the Mexican health-care system as inferior and believed that a lack of support to the institutions to enable doctors, who were already overwhelmed in every way, to perform their work was a problem. Moreover, because of these issues, Mexico is the first country to report deaths of health-care personnel due to COVID-19 [26]. Nevertheless, it is a reality that the doctors themselves are often not in ideal health [27], and they are a reflection of all the problems and health conditions that we discussed earlier. Taken together, all the problems discussed in this section represent the general overview and conditions due to which Mexico has experienced high incidences of COVID-19 infection and deaths. However, this does not explain the rapid spread of the virus due to the general Mexican population's attitude toward the pandemic and its preventive measures.

\section{The attitude of the Mexican population toward the pandemic and their preventive measures}

In this social media era, knowledge and information are now easier to obtain, even more so during a global crisis, such as the COVID-19 pandemic. The Internet, scientific journals, and the news overexpose people to all kinds of information about the virus, while scientists continue to evaluate new data and make novel discoveries about the virus. The mechanism underlying social media's effects on behavioral changes is that the coverage of a pandemic on social media can magnify the public's fear and urge the public to take preventive actions [28]. However, the participants in our study did not appear interested in information about SARS-CoV-2: e.g., only 59\% stated that they were continuously looking for information regarding the progress of the pandemic, and $16 \%$ stated that they preferred to avoid information regarding COVID-19. On actively tracking COVID-19 updates, our findings are not that far off from those of a German study, in which $67.1 \%$ of participants indicated that they had been following media coverage about the COVID-19 outbreak for $>1$ month [29]. However, in contrast to our findings, only $2.7 \%$ of participants in that study (almost eight times less than in our study) did not follow news about COVID-19. Leaving aside disinterest, at least the main message in the Mexican health-care campaign appears to be getting through to the population because almost $99 \%$ of our participants mentioned knowing about the symptoms of COVID-19, and almost $90 \%$ of participants stated that they were aware of where they could go in case of having current symptoms. 
To understand the degree and speed of the spread of the virus in Mexico, it is essential to investigate how Mexicans relate to each other, protect themselves with preventive health-care measures, and follow government instructions. Undoubtedly, one of the factors that contain the virus in developing countries rather tricky is overcrowding in these countries. In our study, 3091 participants (almost $77.19 \%$ ) lived with $>3$ cohabitants, of which at least $87.4 \%$ had one household member who frequently broke social isolation. Even when the participants were constantly exposed to not quarantined people, almost three out of four stated that they were maintaining adequate social distancing measures. However, almost $60 \%$ of participants stated that they knew at least six individuals who were not following proper quarantine measures. This finding indicated that it was easier for people to judge others regarding their social distancing measures. Regarding the effectiveness of being quarantined, a study conducted in China concluded that latent individuals' contact rate is between 6 and 18, representing the possible impact of isolation and quarantine measures on the disease infection rate. These findings suggest that interventions, such as isolation and quarantine, can effectively reduce the peak number of COVID-19 infection cases and delay infection cases' peak time by reducing the contact rate [30]. Another study showed that the infection's epidemic trend mainly depends on quarantine and suspected cases [31]. Worldwide, it appeared easier to stay in social isolation during the early stage of COVID-19 spread. During the initial months of the quarantine, a study conducted in China reported that the public displayed significantly strong support toward quarantine measures throughout the outbreak period, except for locking people up and using imprisonment or other legal sanctions against those who failed to comply with the stringent regulations [31]. However, over the months of 2020, maintaining strict isolation and avoiding large gatherings and events was increasingly complex, and people were more reluctant to follow social distancing measures. The reasons why people no longer wanted to comply with government instructions to maintain social distancing were the need to keep their lives afloat and the ill effects of social distancing. The quarantine has resulted in lifestyle changes such as reduced physical activity and unhealthy diets [32]. Our study participants could not perform strict social distancing measures presented in Table 2 and include the need to keep their jobs, maintain their daily routine, and help family members. However, it again appears more straightforward for people to judge others because when asked about the reasons why they believed that others did not follow the quarantine measures, the most frequent response was related to work, but reasons such as disinterest, despair, and the desire for recreation were also common. Throughout the quarantine in Mexico, different regions have allowed the opening of bars, restaurants, and nightclubs, except for weekends, and even significant events, leaving the general population to decide whether to assist with health measures [33]. These types of measures have been taken by almost every country in the world. One of the main challenges that governments face in a pandemic, such as the COVID-19 pandemic, is ensuring good public health while reducing the adverse economic effects of measures such as country-wide lockdowns. There is an implicit trade-off between economic wealth and COVID-19 cases and deaths [34]. This is a key factor in the snowballing of cases, which prevents the pandemic from coming under control.

In a country where general conditions make a prolonged quarantine unrealistic, the use of preventive measures against the virus becomes a mainstay to control its spread. We asked our study participants 
how often they used preventive measures against COVID-19, and they responded with a high level of use. However, $70 \%$ of participants also answered that $<50 \%$ of their cohabitants used such measures. Some reports on global behavior regarding the use of face masks stated that Mexico is one of the countries with the maximum use of masks [35, 36]. This fact was also announced by the Mexican government [36], and it is in agreement with our findings that approximately $99.5 \%$ of the studied population used face masks. However, in our study, only fifty percent used a certified mask, and the remainder used a homemade or handmade mask that did not meet quality standards and did not confer or guarantee any protection to the user or people around. This means that only one in two Mexicans uses the WHO's primary protection tool against the coronavirus [37]. The use of face masks is supported by science because coronavirus transmission is mainly through aerosol drops exhaled from infected patients, whether symptomatic or not. A Chinese study regarding face mask use concluded that it is reasonable to suggest that face masks can mitigate the current pandemic because they may reduce coronavirus particles in aerosols and respiratory droplets [38]. That is why using measures that protect from aerosols and droplets is also important, such as protective glasses and other equipment. However, the low degree of acceptance of eye protection in our population was alarming. The reasons why our study population did not use the different types of preventive measures against COVID-19 are presented in Tables 3 and 4, and they indicate an economic, social, and educational reality that must be fought with information and health education; otherwise, it will be impossible to stop the COVID-19 contagion.

The WHO has strongly emphasized the importance of carrying out tests to detect cases timely, predominantly asymptomatic cases, and isolate them [39]. However, in developing countries such as Mexico, screening campaigns are limited, and thus it is decided to opt for different models. For example, a model designed at the University of Guadalajara, Mexico, has been used in Jalisco, Mexico, and it detects $100 \%$ of suspected cases with mild symptoms, unlike the Sentinel model proposed by the federal government, which randomly samples one out of 10 suspected patients and does not have a specific screening method in COVID-19 concentrated areas. [40]. Even with these predictive epidemiology models, the lack of a massive rapid and reliable testing campaign leads to difficulty in containing the pandemic because many cases are not being treated or counted. When comparing the number of COVID-19 tests made by country between Latin American countries performed in January 2021, Mexico was ranked 7th, whereas Brazil, Peru, and Colombia were the top-ranked countries [41]. In a world ranking evaluated in December 2020 of tests per million inhabitants, Mexico was ranked 24, in a ranking led by the United Kingdom, the United States, and Russia [42]. A total of 3502 participants (approximately $87.46 \%$ ) in our study had never undergone COVID-19 testing, but 2880 participants $(71.92 \%)$ reported knowing at least one person who had been diagnosed with COVID-19. The lack of tests, together with the people's limited participation to undergo testing, makes the accurate epidemiological tracking of COVID-19 cases and obtaining an adequate count of actual cases rather difficult.

In summary, we found that most participants of our study lived with more than three cohabitants, of which at least one constantly broke social isolation, used noncertified face masks with limited effectiveness, and poorly used other preventive measures against coronavirus. We also found inadequate 
epidemiological monitoring with evidence in the case of our study population. Taken together, this indicates a complicated COVID-19 situation for Mexico.

\section{Conclusions}

The COVID-19 pandemic situation that Mexico faces is a sum of multiple negative factors enhanced by an unexpected event. Moreover, it is impossible to point out a single challenge to overcome because, even though management at different levels has left things to be desired, the general conditions of the population and the Mexican health-care system's state could have been repaired even with different management policies. It is necessary to attack the indicated problems at their roots by starting health education campaigns for the population that will enable people to identify the risk to which they are exposed, decide to be part of the strategy to stop the pandemic, and achieve general habits that can help improve the incidence of chronic diseases and obesity. It is also essential to improve the medical staff's conditions and provide a better hospital infrastructure. Mexico's leaders must reflect on their stance against the coronavirus and look for ways to increase the provision of aid exponentially. We believe that for Mexico to overcome the current pandemic situation, each individual must be involved to stop the rapid spread of the virus. Health-care personnel must be supported, empowered, and dignified. Tools must be provided to people so that the preventive measures they decide to use are realistic, such as providing monetary support so that people can quarantine without the need to go out to earn their livelihood. Mexico can overcome the pandemic if it finds strength in the unity of its people.

\section{Abbreviations}

Angiotensin-converting enzyme 2 (ACE2)

Case Fatality Rate (CFR)

Coronavirus Disease 2019 (COVID-19)

Elementary Education Group (EEG)

Fear of COVID-19 Scale (FCV-19S)

Higher Education Group (HEG)

National Institute of Statistics and Geography (INEGI)

World Health Organization (WHO)

\section{Declarations}

\section{Ethics approval and consent to participate}


Informed consent was obtained from each participant. The surveys were anonymous to guarantee the confidentiality of each participant. The authors assert that all procedures contributing to this work comply with the relevant national and institutional committees' ethical standards on human experimentation and with the Helsinki Declaration of 1975, as revised in Fortaleza, Brazil 2013. The study protocol was submitted to ClinicalTrials.gov and registered using the identifier: NCT04420416.

\section{Availability of data and materials}

All data generated or analyzed during this study are included in this published article (and its supplementary information files).

\section{Competing interests}

The authors declare that they have no competing interests.

\section{Funding}

The authors received no financial support for the research, authorship, and publication of this article.

\section{Authors' contributions}

JCIP conceived of the study. All authors contributed to the study's conception and design. JMCM, EARE, and OMRL prepared the study material. MLZ, RCMA, CFO, YLAM, JABG, and PFB assisted with the student recruitment process and distribution of the surveys. FJBC, JCIP, and AGO performed data management and analysis. RZO, ECP, and JHSP prepared figures 1-4. JCIP and GCG wrote the first draft of the manuscript. All authors critiqued all versions of the manuscript. All authors read and approved the final manuscript.

\section{Acknowledgments}

The authors wish to acknowledge all health-care personnel who are working against COVID-19 in Mexico.

\section{References}

1. Mojica-Crespo R, Morales-Crespo MM. [Pandemic COVID-19, the new health emergency of international concern: a review]. Semergen. 2020;46:65-77.

2. Lee SA. Coronavirus Anxiety Scale: a brief mental health screener for COVID-19 related anxiety. Death Stud. 2020;44(7):393-401.

3. Meneses-Navarro S, Freyermuth-Enciso MG, Pelcastre-Villafuerte BE, Campos-Navarro R, MeléndezNavarro DM, Gómez-Flores-Ramos L. The challenges facing indigenous communities in Latin America as they confront the COVID-19 pandemic. Int J Equity Health. 2020;19:63.

4. Méndez-Arriaga F. The temperature and regional climate effects on communitarian COVID-19 contagion in Mexico throughout phase 1. Sci Total Environ. 2020;735:139560. 
5. Acuña-Zegarra MA, Santana-Cibrian M, Velasco-Hernandez JX. Modeling behavioral change and COVID-19 containment in Mexico: a trade-off between lockdown and compliance. Math Biosci. 2020;325:108370.

6. COVID-19 Tablero México - CONACYT - CentroGeo - Geolnt - DataLab. https://datos.covid19.conacyt.mx/\#DOView. Accessed March 13, 2021.

7. Mortality analyses-Johns Hopkins Coronavirus Resource Center. https://coronavirus.jhu.edu/data/mortality. Accessed March 13, 2021.

8. Krauze, L. Opinion: AMLO shows Mexico is not ready for the coronavirus. The Washington Post. https://www.washingtonpost.com/opinions/2020/03/18/mexico-is-not-ready-coronavirus-just-lookamlos-behavior/. Accessed March 13, 2021.

9. Associated Press. WHO Chief: Mexico in "Bad Shape" with coronavirus pandemic. US News. https://www.usnews.com/news/health-news/articles/2020-12-01/who-chief-mexico-in-bad-shapewith-coronavirus-pandemic. Accessed March 13, 2021.

10. Monroy, J. En México, 15.4 millones de personas de 60 años o más. [In Mexico, 15.4 million people aged 60 and over] El Economista. https://www.eleconomista.com.mx/politica/En-Mexico-15.4millones-de-personas-de-60-anos-o-mas-20200326-0008.html Accessed March 13, 2021.

11. Miranda, P. Adultos mayores, grupo con más muertes por Covid-19 en México. [Older adults, group with the most deaths from Covid-19 in Mexico]. El Universal. https://www.eluniversal.com.mx/nacion/adultos-mayores-grupo-con-mas-muertes-por-covid-19-enmexico. Accessed March 13, 2021.

12. Kang SJ, Jung SI. Age-related morbidity and mortality among patients with COVID-19. Infect Chemother. 2020;52(2):154-64.

13. Hua W, Xiaofeng L, Zhenqiang B, Jun R, Ban W, Liming L. Consideration on the strategies during epidemic stage changing from emergency response to continuous prevention and control. Chinese $\mathrm{J}$ Endem. 2020;41(2):297-300.

14. Hernández-Galdamez DR, González-Block MÁ, Romo-Dueñas DK, Lima-Morales R, Hernández-Vicente IA, Lumbreras-Guzmán $\mathrm{M}$, et al. Increased risk of hospitalization and death in patients with COVID-19 and pre-existing noncommunicable diseases and modifiable risk factors in Mexico. Arch Med Res. 2020;51(7):683-9.

15. Centers for Disease Control and Prevention: Hispanic/Latino Americans and Type 2 Diabetes. https://www.cdc.gov/diabetes/library/features/hispanic-diabetes.html. Accessed March 13, 2021.

16. Ojeda, R. Diabetes en México: así se comporta la segunda causa de muerte en el país[Diabetes in Mexico: this is how the second cause of death behaves in the country.] Milenio. https://www.milenio.com/ciencia-y-salud/diabetes-en-mexico-2020-estadisticas-y-porcentaje. Accessed March 13, 2021.

17. Sosa-Rubí SG, Seiglie JA, Chivardi C, Manne-Goehler J, Meigs JB, Wexler DJ, et al. Incremental risk of developing severe COVID-19 among Mexican patients with diabetes attributed to social and health care access disadvantages. Diabetes Care. 2021;44(2):373-80. 
18. Piña-Pozas M, Araujo-Pulido G, Castillo-Castillo. Hipertensión arterial un problema de salud pública en México. [Arterial hypertension a public health problem in Mexico.] Gobierno de México. https://www.insp.mx/avisos/5398-hipertension-arterial-problema-salud-publica.html. Accessed March 13, 2021.

19. Omar MB. Covid-19 and the angiotensin-converting enzyme (ACE2): areas for research. Heart Lung. 2020;49(4):351.

20. Aronson JK, Ferner RE. Drugs and the renin-angiotensin system in covid-19. BMJ. 2020;369:m1313.

21. INEGI. Estadísticas a propósito del día mundial contra la obesidad (12 de Noviembre). [Statistics about the world day against obesity (November 12)]. Comunicado de prensa https://www.inegi.org.mx/contenidos/saladeprensa/aproposito/2020/EAP_Obesidad20.pdf Accessed November 20, 2020.

22. Petrova D, Salamanca-Fernández E, Rodríguez Barranco M, Navarro Pérez P, Jiménez Moleón JJ, Sánchez MJ. Obesity as a risk factor in COVID-19: possible mechanisms and implications. Aten Primaria. 2020;52(7):496-500.

23. Simonnet A, Chetboun M, Poissy J, Raverdy V, Noulette J, Duhamel A, et al. High prevalence of obesity in severe acute respiratory syndrome coronavirus-2 (SARS-CoV-2) requiring invasive mechanical ventilation. Obesity. 2020;28(7):1195-9.

24. López-Feldman A, Heres D, Marquez-Padilla F. Air pollution exposure and COVID-19: a look at mortality in Mexico City using individual-level data. Sci Total Environ. 2021;756:143929.

25. Taylor L. Covid-19: How denialism led Mexico's disastrous pandemic control effort. BMJ. 2020;371:m4952.

26. El Financiero. México, primer lugar mundial en personal de salud fallecido por COVID-19: Amnistía Internacional. [Mexico, first place in the world in health personnel deceased by COVID-19: Amnesty International]. El Financiero. https://www.elfinanciero.com.mx/salud/mexico-primer-lugar-mundialen-personal-de-salud-fallecido-por-covid-19-amnistia-internacional. Accessed March 13, 2021.

27. Agren D. Understanding Mexican health worker COVID-19 deaths. Lancet. 2020;396(10254):807.

28. Costantino C, Restivo V, Ventura G, D’Angelo C, Randazzo MA, Casuccio N, et al. Increased vaccination coverage among adolescents and young adults in the district of Palermo as a result of a public health strategy to counteract an 'epidemic panic.' Int J Environ Res Public Health. 2018;15(5):1014.

29. Siebenhaar KU, Köther AK, Alpers GW. Dealing with the COVID-19 infodemic: distress by information, information avoidance, and compliance with preventive measures. Front Psychol. 2020;11:2981.

30. Hou C, Chen J, Zhou Y, Hua L, Yuan J, He S, et al. The effectiveness of quarantine of Wuhan city against the corona virus disease 2019 (COVID-19): a well-mixed SEIR model analysis. J Med Virol, 2020;92(7):841-8.

31. Song W, Sawafta FJ, Ebrahem BM, Jebril MA. Public attitude towards quarantine during the COVID19 outbreak. Epidemiol Infect. 2020;148:e220. 
32. Rehman H, Ahmad MI. COVID-19: quarantine, isolation, and lifestyle diseases. Arch Physiol Biochem. 2020. doi:10.1080/13813455.2020.1833346.

33. Mendoza, J. Conciertos en México se adaptan a la nueva normalidad del covid-19. [Concerts in Mexico adapt to the new normal of covid-19.] Milenio.

https://www.milenio.com/espectaculos/musica/conciertos-en-mexico-se-adaptan-a-la-nuevanormalidad-del-covid-19. Accessed January 5, 2021

34. Redacción TYT. Comercio y turismo en Jalisco, con horarios cortos y cierres en fin de semana. [Commerce and tourism in Jalisco, with short hours and closings on weekends.] Revista Transportes y Turismo. https://www.tyt.com.mx/nota/comercio-y-turismo-en-jalisco-con-horarios-cortos-y-cierresen-fin-de-semana. Accessed January 5, 2021

35. Ponce H. Optimization of the containment levels for the reopening of Mexico City due to COVID-19. IEEE Latin America Transactions. 2020;100(1e):4416.

36. Redacción. México, país que más usa cubrebocas de manera voluntaria: estudio compartido por López-Gatell. [Mexico, the country that uses face masks on a voluntary basis: study shared by LópezGatell]. El Universal. https://www.eluniversal.com.mx/nacion/mexico-pais-que-mas-usa-cubrebocasde-manera-voluntaria-estudio-compartido-por-lopez-gatell. Accessed January 5, 2021

37. World Health Organization. When and how to use masks. https://www.who.int/emergencies/diseases/novel-coronavirus-2019/advice-for-public/when-andhow-to-use-masks

38. Wong SH, Teoh JYC, Leung CH, Wu WKK, Yip BHK, Wong MCS, et al. COVID-19 and public interest in face mask use. Am J Respir Crit Care Med. 2020;202(3):453-55.

39. The Guardian. "Test, test, test": WHO calls for more coronavirus testing - video. https://www.theguardian.com/world/video/2020/mar/16/test-test-test-who-calls-for-morecoronavirus-testing-video

40. Hospital Civil de Guadalajara. http://www.hcg.udg.mx/infAnuncio.php?IDBol=1811\&IDFot=1

41. Statista. Tests de COVID-19 en países de América Latina 2021. https://es.statista.com/estadisticas/1110532/covid-19-numero-de-pruebas-en-paiseslatinoamericanos/

42. Statista. Tasa de tests del coronavirus en países más afectados del mundo 2020. https://es.statista.com/estadisticas/1107740/covid-19-tasa-de-pruebas-realizadas-en-paisesseleccionados-del-mundo/

\section{Additional File}

Additional file 1 is not available with this version 